\title{
Desain User Interface Personal Asisten Keuangan Digital
}

\author{
Rakhma Shafrida Kurnia, Rifda Faticha Alfa Aziza* \\ Informatika, Fakultas Ilmu Komputer, Universitas Amikom Yogyakarta \\ Jl. Ring Road Utara, Condong Catur, Sleman, Yogyakarta, Indonesia, Telp. (0274) 884201-207 \\ *e-mail: rifda@amikom.ac.id
}

(received: 23 Februari 2021, revised: 12 April 2021, accepted: 4 September 2021)

\begin{abstract}
Abstrak
Literasi keuangan menjadi hal yang penting seiring meningkatnya popularitas layanan keuangan digital karena dapat berpengaruh terhadap bagaimana seseorang mengelola keuangannya dan berakibat pada kesehatan keuangan seseorang di masa depan. Untuk meningkatkan literasi keuangan dapat dengan membaca buku, artikel maupun dukungan aplikasi personal asisten keuangan yang memenuhi kebutuhan pengguna. Penelitian ini bertujuan untuk memahami pengalaman pengguna dalam mengelola keuangan personal sehingga peneliti dapat mendefinisikan kebutuhan pengguna untuk dijadikan pertimbangan dalam merancang aplikasi pengelolaan keuangan personal. Metode yang digunakan yaitu five planes method yang terdiri dari strategy, scope, structure, skeleton dan surface dengan pendekatan analisis fenomenologis interpretatif. Penelitian dilakukan dengan melakukan survey terhadap 41 orang dan dilanjutkan dengan wawancara analisis fenomenologis interpretatif dengan tujuan untuk lebih memahami kebutuhan target pengguna. Penelitian dilanjutkan dengan analisis dan pembuatan user journey map yang kemudian digunakan untuk merancang user flow. Hasil akhir penelitian berupa rekomendasi antarmuka presisi tinggi aplikasi asisten keuangan personal yang mencakup semua fitur yang dibutuhkan oleh pengguna.
\end{abstract}

Kata kunci: antarmuka, asisten personal, aplikasi, user experience

\begin{abstract}
Financial literacy becomes important as the popularity of digital financial services increases because it can affect how a person manages his finances and has an impact on one's financial health in the future. To improve financial literacy, someone can read books, articles or use financial personal assistant applications that meet user needs. This study aims to understand user experience in managing personal finance so that researchers can define user needs to be considered in designing personal financial management applications. The method used is the five planes method consisting of strategy, scope, structure, skeleton and surface with an interpretive phenomenological analysis approach. The research was conducted by conducting a survey of 41 people and followed by Interpretive phenomenological analysis interview with the aim of better understanding the needs of the target users. The research continued with analysis and creation of a user journey map which was then used to design user flow. The final result of the research is a recommendation for a high-fidelity interface for a personal financial assistant application that includes all the features needed by users.
\end{abstract}

Keywords: interface, personal assistant, mobile, user experience

\section{Pendahuluan}

Literasi keuangan membantu seseorang untuk membedakan antara keputusan keuangan untuk memenuhi kebutuhan yang bermanfaat atau yang akan merusak masa depan keuangan. Mempunyai rencana keuangan dapat membantu dalam memenuhi kebutuhan jangka pendek dan jangka panjang tanpa melampaui batas pemasukan. Untuk memastikan semua aset pendapatan dan pengeluaran dipenuhi dapat menggunakan penasehat keuangan. Penasehat keuangan adalah aktivitas mengelola keuangan oleh individu maupun keluarga yang bertujuan membelanjakan sumber daya moneter, menganggarkan, menyimpan dari waktu ke waktu dengan pertimbangan risiko keuangan serta peristiwa kehidupan masa depan [1]. 
Masalah keuangan merupakan hal besar yang harus dipikirkan dalam perspektif yang jauh lebih luas. Pengelolaan keuangan yang baik tidak hanya menjadi kebutuhan perusahaan maupun organisasi, seorang individu juga memiliki kebutuhan mengelola keuangannya sendiri. Tingkat literasi keuangan yang rendah dapat menyebabkan individu melakukan pengambilan keputusan keuangan hanya menggunakan spekulasi, bukan berdasarkan analisa keuangan yang bersumber dari data historis. Apabila keputusan yang diambil ternyata salah atau tidak tepat akan berdampak serius terhadap kesehatan keuangan di masa depan [2]. Dalam SNLKI 2017, literasi keuangan telah menjadi keterampilan hidup setiap individu, hal ini dilakukan agar seseorang dapat merencanakan dan melakukan pengelolaan keuangan dengan baik untuk tercapainya kesejahteraan [3].

Saat ini perkembangan Industri 4.0 mendukung adanya integrasi dari teknologi digital, internet dan model industri konvensional untuk menghadirkan produk dan layanan dengan cara yang lebih efisien [4]. Pemanfaatan teknologi dibidang keuangan dengan adanya dompet digital. Data Bank Indonesia menyebutkan jumlah uang elektronik yang beredar mengalami kenaikan mulai dari tahun 2016 hingga Februari 2020. Namun peningkatan signifikan terjadi di tahun 2018 total Rp.167.205.578 kemudian tahun 2019 naik 16x lipat dengan total Rp.2.677.040.259. Banyaknya transaksi menggunakan uang elektronik ini membuat $\mathrm{BI}$ harus memperjelas peraturan dalam transaksi uang elektronik dengan diterbitkannya Peraturan Bank Indonesia (PBI) No. 11/12/PBI/2009 tanggal 13 April 2009 tentang Uang Elektronik [5].

Meningkatnya transaksi uang elektronik dari waktu ke waktu mengindikasikan uang elektronik semakin lazim digunakan oleh masyarakat Indonesia. Kemudahan dalam penggunaan dan didorong oleh maraknya promo oleh penyedia platform uang elektronik mendorong masyarakat Indonesia untuk menggunakan uang elektronik untuk memenuhi kebutuhan sehari-hari. Menurut peneliti LIPI dalam penelitian yang berjudul Less Cash Society: Menakar Mode Konsumerisme Baru Kelas Menengah Indonesia [6], teknologi berperan besar dalam mendorong kelas menengah Indonesia agar lebih konsumtif melalui kehadiran alat pembayaran elektronik non-tunai. Di negara maju, kehidupan menggunakan uang elektronik membentuk karakter belanja impulsif kelas menengah, dimana orang membeli barang tanpa ada rencana sebelumnya [6]. Oleh karena itu sangat penting bagi pengguna dompet digital untuk memiliki literasi keuangan. Menurut sebuah studi yang dilakukan oleh Insight MarkPlus,45,7\% orang dari kelas menengah merencanakan masa depan mereka, termasuk keuangan masa depan. Untuk mengelola keuangan pribadi, para konsumen kelas menengah tidak memiliki cukup waktu meskipun mereka menyadari bahwa mereka membutuhkan nasihat dari penasehat keuangan [7]. Biaya yang relatif mahal dibandingkan dengan pengeluaran hariannya menjadi halangan untuk menggunakan jasa penasehat keuangan. Kelas menengan memerlukan perencanaan keuangan yang praktis serta komprehensif. Di sisi lain, terdapat aplikasi ponsel yang dapat membantu untuk mengelola keuangan pribadi seperti Monefy, Finansialku, dan Money Lover. Ketiga aplikasi tersebut mempunyai fitur utama untuk mencatat keuangan pribadi seperti pendapatan dan pengeluaran. Ketiga aplikasi tersebut memiliki kekurangan yaitu tidak menyediakan fitur penasehat keuangan pribadi.

Dalam penelitian ini dilakukan studi tentang pengalaman seseorang dalam melakukan pengelolaan keuangan personalnya sehingga dapat menjawab apa saja kebutuhan seseorang ketika melakukan pemgelolaan keuangan menggunakan aplikasi manajemen keuangan. Pengalaman pengguna didefinisikan oleh ISO sebagai persepsi pengguna yang dihasilkan dari penggunaan sistem, produk atau layanan. Merancang pengalaman pengguna produk digital bertujuan agar hasil akhir benar-benar menyelesaikan masalah pengguna dan membantu pengguna mencapai tujuan mereka [8]. Metode dalam penelitian ini menggunakan analisis fenomenologis interpretatif dan Five Planes Method. Analisis fenomenologis interpretatif digunakan untuk mempelajari secara rinci bagaimana pengalaman seseorang dalam mengalami situasi [9]. Tujuannya adalah untuk sedekat mungkin dengan perspektif user untuk mengenal dunia emosional dan sosial mereka. Analisis ini dapat menjadi metode yang tepat untuk menganalisis pengalaman dengan suatu produk atau layanan dan apa arti pengalaman itu bagi pengguna [10]. Untuk perancangan antarmuka dan pengalaman pengguna digunakan metode Five Planes Method yang terdiri dari 5 elemen yakni strategy plane, scope plane, structure plane, skeleton plane, dan surface plane. Setiap tahapan pada Five Planes Method berfungsi untuk memecah tugas dalam memahami pengalaman pengguna, agar dapat memahami masalah secara keseluruhan [11]. 


\section{Tinjauan Literatur}

Linder dan Arvola [10] meneliti tentang analisis fenomenologis interpretatif dengan tujuan mengetahui bagaimana pendekatan tersebut dapat berkontribusi dalam penelitian pengalaman pengguna dengan menguji pengalaman para imigran di Swedia dalam mendapatkan pelayanan di tahap perkenalan pasar kerja. Hasil dari analisis menyatakan bahwa analisis fenomenologis interpretatif berkontribusi pada penelitian pengalaman pengguna pada proses desain interaksi dengan cara menginvestigasi pengalaman pengguna dapat memberikan wawasan yang sesuai untuk desain layanan dan inovasi untuk layanan.

Strohmann et al [12] membuat pedoman untuk desain representasional dan interaksi virtual asisten di dalam kendaraan, yaitu tentang apa yang harus dipertimbangkan oleh perancang saat membuat asisten virtual untuk kendaraan dengan tujuan untuk memberikan pengalaman pengguna yang meyakinkan dan memastikan bahwa menggunakan asisten virtual di dalam kendaraan sangat bermanfaat untuk membuat hidup penggunanya lebih mudah. Penelitian ini menghasilkan 14 poin persyaratan untuk aplikasi asisten virtual di dalam kendaraan serta 54 pedoman desain untuk desain interaksi asisten virtual berdasarkan literatur penelitian sebelumnya serta hasil wawancara dengan pakar. Penelitian yang dilakukan oleh Dewi et al [13], mengenai perbandingan atau komparasi alat bantu pengelolaan keuangan personal berbasis mobile. Pada penelitian tersebut dilakukan komparasi studi pada tiga aplikasi keuangan yaitu Wallet, Uangku dan Monefy untuk mengetahui kelebihan dan kekurangan fitur aplikasi serta mengetahui fasilitas yang dibutuhkan oleh pengguna. Hasil dari penelitian yaitu terdapat berbagai kelebihan dan kekurangan dari masing-masing aplikasi. Aplikasi Wallet memiliki fitur yang menyediakan fitur tambahan seperti jenis laporan keuangan. Aplikasi Monefy menyediakan fitur nilai tukar mata uang. Penelitian yang dilakukan oleh Cowan et al [14] mengkaji tentang alasan pengalaman pengguna yang jarang menggunakan aplikasi personal asisten. Hasil dari penelitian yaitu alasan pengguna jarang menggunakan dan memilih untuk tidak menggunakan aplikasi personal asisten diantaranya karena adanya batasan interaksi, kekhawatiran seputar privasi dan monetisasi serta transparansi data.

Dalam penelitian ini dilakukan studi tentang pengalaman seseorang dalam pengelolaan keuangan personal agar dapat menjawab apa saja sebenarnya kebutuhan seseorang ketika menggunakan aplikasi pengelolaan keuangan personal sehingga dapat menjadi pedoman dalam desain antarmuka aplikasi personal asisten untuk pengelolaan keuangan.

\section{Metode Penelitian}

Penelitian ini terdiri dari 2 fase yaitu fase persiapan dan fase pelaksanaan. Adapun detail dari alur penelitian yang akan dilakukan yaitu seperti pada Gambar 1. 


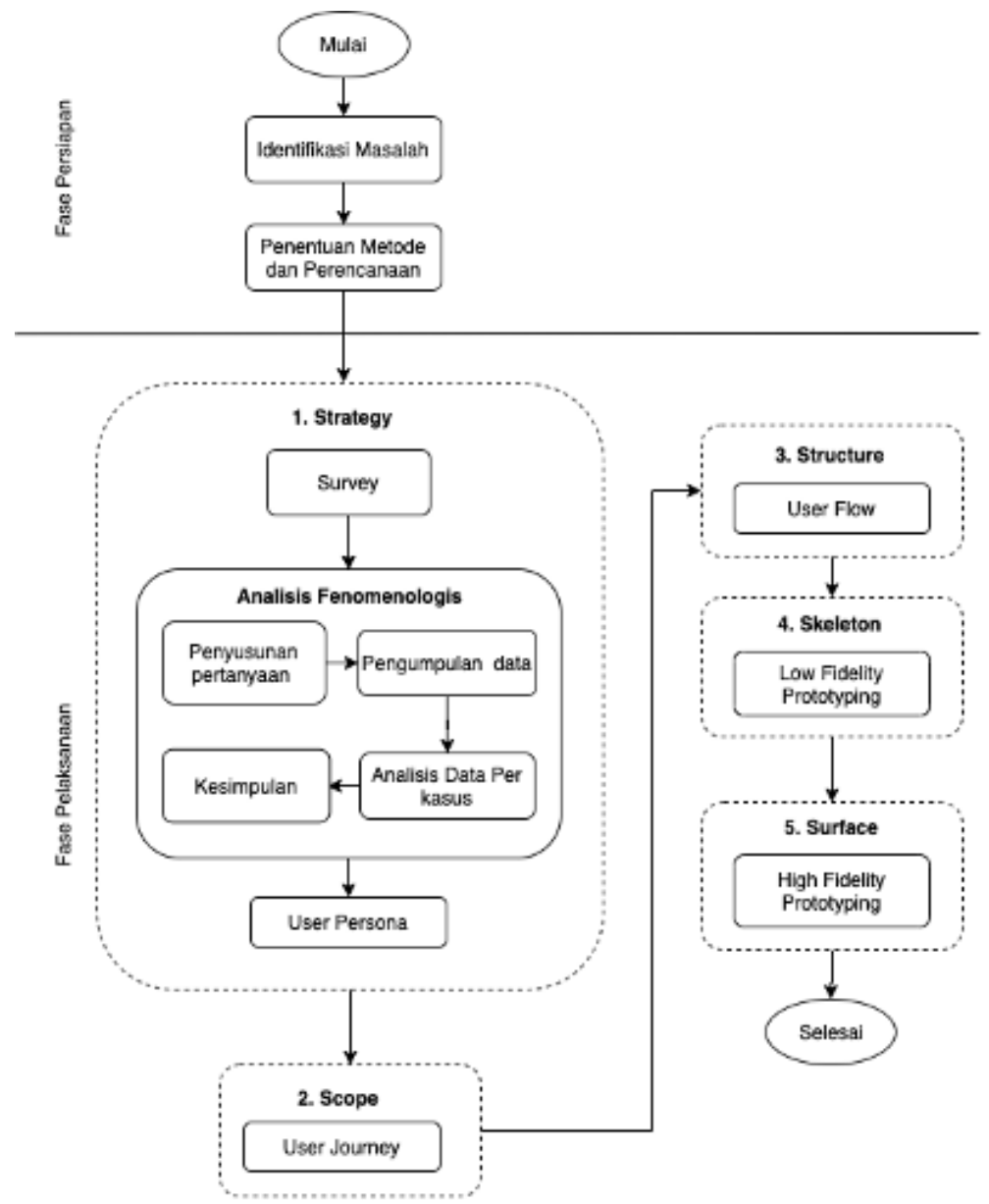

Gambar 1. Alur Penelitian

\subsection{Fase Persiapan}

Proses identifikasi masalah dilakukan dengan melakukan empathize, melihat permasalahan yang ada di sekitar terkait pengelolaan keuangan dan melihat perkembangan industri dalam hal ini berfokus pada bidang layanan keuangan digital. Setelah itu dilakukan penentuan metode dan perencanaan yang akan digunakan untuk melakukan penelitian.

\subsection{Fase Pelaksanaan}

Fase pelaksanaan mengadaptasi Five Plane Method dan analisis fenomenologi. Tahap awal yaitu dengan melakukan survey terhadap 41 orang yang dilanjutkan dengan interview analisis fenomenologis interpretative untuk mengidentifikasi kebutuhan pengguna. Five Planes Method adalah kerangka kerja untuk menggambarkan bagaimana pengalaman pengguna dapat dirancang [11]. Dengan kerangka kerja ini, pengalaman pengguna akan lebih mudah dijelaskan dalam bentuk model konseptual, baik dari segi pemecahan masalah maupun cara penyelesaiannya. Kerangka kerja ini terdiri dari lima bagian yaitu surface, skeleton, structure, scope dan strategy. Setiap elemen akan bergantung pada elemen di bawahnya, sehingga perancangan harus dimulai dari elemen paling bawah seperti yang diilustrasikan pada Gambar 2 berikut. 


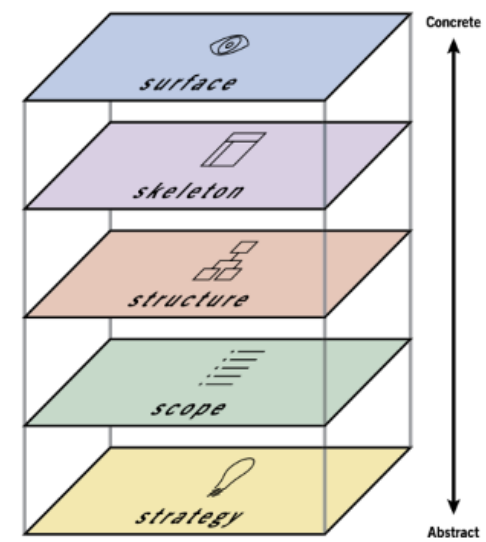

Gambar 2. Five Planes Method [11]

\section{Strategy}

Pada tahap strategy dilakukan validasi pengalaman seseorang dalam pengelolaan keuangan pribadinya sehingga dapat diidentifikasi kebutuhan dan tujuannya dalam melakukan pengelolaan keuangan [8]. Untuk mengidentifikasi kebutuhan pengguna dengan jelas, peneliti melakukan proses survey dan analisis fenomenologis berupa interview. Menurut Idrus [15] fenomenologi adalah penelitian kualitatif yang mencakup fenomena seperti persepsi, pemikiran, kemauan, dan keyakinan subjek tentang sesuatu di luar dirinya. Sedangkan tujuan dari analisis fenomenologis menurut Sukmadinata [15] adalah untuk menemukan makna dari hal-hal yang esensial atau mendasar dari pengalaman hidup seseorang. Tahap-tahap Interpretative Phenomenological Analysis adalah sebagai berikut: 1) Reading and re-reading; 2) Initial noting; 3) Developing Emergent themes; 4) Searching for connections across emergent themes; 5) Moving the next cases; and 6) Looking for patterns across cases.

2. Scope

Pada tahapan scope didefinisikan kebutuhan fungsional dan kebutuhan konten yang diperlukan untuk memenuhi kebutuhan pengguna [8]. Tujuan dari tahapan ini yaitu bagaimana cara agar tujuan produk dan kebutuhan pengguna dapat dipenuhi. Cara untuk memetakan kebutuhan user dengan jelas yaitu menggunakan user journey map dengan tujuan memvisualisasikan langkah-langkah yang diambil oleh pengguna untuk membayangkan peristiwa dan interaksi dalam sebuah proses [16]. Gambaran perjalanan atau pengalaman pengguna pada user journey map yang dibuat diadopsi dari hasil survey dan wawancara pada analisis fenomenologis. User Journey Map adalah contoh penting dari alat yang mendukung proses berpikir kolaboratif dengan memetakan topik diskusi secara visual yang mendorong para desainer secara kolaboratif mengeksplorasi dan mengenali pola-pola baru dengan meninjau kembali fragmen-fragmen informasi serta mengelaborasi ide-ide baru [17]. User journey map dapat bermacam-macam bentuk, elemen-elemen umum diantaranya adalah (1) persona (siapa), (2) skenario yang akan diperiksa (apa), (3) fase dari perjalanan, (4) Tindakan yang dilakukan pengguna, (5) pikiran pengguna, dan (6) pengalaman emosional pengguna selama perjalanan mereka, dapat dilengkapi dengan kutipan atau video dari penelitian. Bagian terakhir yaitu (7) temuan yang dapat menggambarkan wawasan dan pain point yang ditemukan serta peluang untuk kemajuan kedepannya.

3. Structure

Tahapan structure menjelaskan arsitektur informasi dari aplikasi yang dirancang. Pada tahap ini dilakukan perancangan user flow dan desain struktur halaman. User flow untuk menggambarkan alur saat pengguna menggunakan produk agar tujuan pengguna terpenuhi [18]. Desain struktur halaman digunakan untuk mengetahui hubungan antar konten yang tersedia dalam antarmuka secara keseluruhan [19]. 


\section{Skeleton}

Tahap skeleton yaitu tahapan merancang bentuk visual interface yang akan dibangun, serta mengatur tata letak elemen-elemen yang membuat user dapat berinteraksi dengan fungsionalitas sistem yang ada pada interface. Pada tahap ini, sketsa digunakan untuk menuangkan ide gambaran pada antarmuka secara cepat. Kemudian dilakukan pembuatan wireframe untuk memetakan peletakan konten [18].

5. Surface

Surface merupakan tahapan akhir dalam proses pembuatan desain user interface. Pada tahap ini dilakukan pembuatan prototipe presisi tinggi berupa yang memperjelas tampilan visual berupa tata letak, warna, tipografi, dan standardisasi ukuran elemen dalam aplikasi [8].

\section{Hasil dan Pembahasan}

\subsection{Fase Persiapan}

Pada fase ini, peneliti melakukan empathize, melihat permasalahan yang ada di sekitar terkait pengelolaan keuangan dan melihat perkembangan industri dalam hal ini berfokus pada bidang layanan keuangan digital. Penggunaan uang elektronik pada dompet digital di Indonesia semakin banyak digunakan. Tanpa adanya pengetahuan literasi keuangan yang baik, pengguna menjadi konsumtif dan keuangan personal menjadi tidak sehat. Sementara itu, konsumen kelas menengah tidak memiliki cukup waktu untuk mengelola keuangan pribadi dan beberapa dari mereka tidak dapat mengelola pendapatan meskipun mereka menyadari bahwa mereka membutuhkan nasihat dari penasehat keuangan. Biaya jasa penasihat keuangan yang relatif mahal bagi konsumen kelas menegah sehingga menjadi halangan dalam menggunakan jasa penasehat keuangan [7]. Peneliti melakukan perbandingan terhadap aplikasi ponsel yang dapat membantu untuk mengelola keuangan pribadi seperti Monefy, Finansialku, dan Money Lover. Ketiga aplikasi tersebut mempunyai fitur utama untuk mencatat keuangan pribadi seperti pendapatan dan pengeluaran, akan tetapi memiliki kekurangan yaitu tidak menyediakan fitur penasehat keuangan.

Berdasarkan permasalahan tersebut, maka penelitian ini bertujuan memahami pengalaman seseorang dalam mengelola keuangan pribadinya untuk mengidentifikasi kebutuhan seseorang dalam pengelolaan keuangan personal sehingga dapat diimplementasikan dalam desain interface aplikasi personal asisten keuangan yang dapat membantu masyarakat sebagai asisten keuangan personal. Penelitian ini mengadopsi five planes method yang dikenalkan oleh J.J. Garrett [11] dan analisis fenomenologis. Five planes method digunakan pada proses membangun user interface dan memahami masalah-masalah yang ada pada pengalaman pengguna. Sedangkan analisis fenomenologi digunakan untuk memahami pengalaman seseorang saat menganalisa kebutuhan sistem. Analisis fenomenologi masuk kedalam five planes method pada tahapan strategy. Five planes method dipilih karena dengan metode ini pengalaman pengguna suatu produk akan lebih mudah dijelaskan dalam bentuk model konseptual, baik dari segi masalah yang dipecahkan dan cara mengatasinya [8]. Sedangkan analisis fenomenologi dilakukan pada tahap strategy karena dapat digunakan untuk mempelajari secara rinci bagaimana pengalaman seseorang dalam mengalami situasi.

\subsection{Fase Pelaksanaan}

\subsubsection{Tahap Strategy}

Fokus utama dari tahapan strategy adalah mengidentifikasi permasalahan, kebutuhan serta tujuan seseorang dalam pengelolaan keuangan. Hasil dari tahap strategy yaitu data yang mendukung untuk membuat user persona dan tahapan perancangan berikutnya. Berikut adalah detail dari proses survey, analisis fenomenologis dan user persona.

\subsubsection{Survey}

Survey dilakukan pada 41 responden dimana sebanyak 95\% telah melakukan pengelolaan terhadap keuangannya berupa pencatatan arus kas. $41 \%$ diantaranya telah melakukan pengelolaan keuangan secara detail mencakup penganggaran hingga investasi sedangkan 58\% belum melakukan pengelolaan keuangan hingga ke tahap tersebut. Sebanyak 7\% dari keseluruhan responden belum pernah sama sekali mencatat arus kas (pengeluaran dan pemasukan) dengan alasan belum merasa perlu, tidak praktis, tidak sempat dan malas. Hal ini dapat menjadi peluang untuk membuat 
rancangan aplikasi yang dapat mengedukasi user dan mudah atau praktis digunakan. Berkaitan dengan tujuan keuangan, $47 \%$ responden mencatat keuangan karena ingin mengidentifikasi pengeluaran yang tidak perlu, 26,5\% sudah pada tahap investasi sehingga ingin lebih disiplin dan sisanya hanya ingin mengetahui arus kas dalam kurun waktu tertentu. Sedangkan alasan responden tidak mencatat arus kas secara rutin sebanyak 60\% adalah karena lupa. Alasan lainnya adanya transaksi sampai dini hari dan karena sibuk sehingga tak sempat. Sebanyak 55,9\% responden sudah pernah menggunakan aplikasi pengelolaan keuangan untuk membantu mereka namun 47,4\% diantaranya sudah tidak menggunakannya lagi dengan alasan karena tampilan aplikasi yang tidak mudah dipahami, fitur pada aplikasi kurang memenuhi kebutuhan secara personal, sering lupa mencatat rutin, aplikasi tidak terkoneksi akun bank dan e-money, aplikasi kebanyakan berbayar untuk menggunakannya, dan terakhir karena lebih nyaman menggunakan tampilan desktop.

Peneliti juga meminta responden untuk memberikan masukan yang mereka butuhkan pada aplikasi asisten pengelolaan keuangan sehingga didapatkan hasil sebagai berikut :

1. Dapat terkoneksi dengan akun bank dan e-money

2. Dapat memberikan notifikasi pengingat untuk mencatat, limit penggunaan dan kemajuan dalam mengejar tujuan keuangan

3. Ada kategori tujuan keuangan seperti tabungan dan investasi

4. Ada prediksi resiko keuangan \& solusinya

5. Terdapat review arus kas yang dinamis per periode dengan grafik

6. Dapat mengedukasi secara personal sesuai dengan profil pengguna

7. Dapat memberikan informasi seputar keuangan yang sesuai dengan kategori tujuan keuangan pengguna

\subsubsection{Analisis Fenomenologis Interpretatif}

Bentuk kegiatan tahap ini pertama kali adalah memilih 4 orang partisipan dari responden survey yang memiliki permasalahan dalam pengelolaan keuangan dan mempunyai tujuan dalam pengelolaan keuangannya. Partisipan dipilih dari segi demografi yaitu partisipan berjenis kelamin wanita berusia rentang antara 20 hingga 39 tahun(millennial) dari kelas ekonomi menengah. Hal tersebut dilakukan dengan tujuan dapat mewakili calon pengguna sesungguhnya. Pemilihan kategori partisipan tersebut karena generasi millennial kelas menengah memiliki daya beli yang kuat dan memiliki kesadaran pada produk keuangan [20].

Tahap berikutnya proses wawancara terkait bagaimana partisipan melakukan pengelolaan keuangan. Transkrip wawancara dari rekaman audio diubah ke dalam transkrip dalam bentuk tulisan. Kemudian tahap kedua yaitu initial noting, transkrip dibaca berulang kali untuk mendalami data yang diperoleh dan membantu analisis yang lebih menyeluruh. Tahap ini peneliti dapat mencatat sesuatu yang menarik dari transkrip. Tujuan analisis ini untuk menghasilkan catatan dan komentar yang komprehensif dan detail. Langkah yang dilakukan peneliti dimulai dengan membaca transkrip kemudian mencari teks yang bermakna, penting atau menarik. Tabel 1 adalah contoh salah satu teks wawancara.

\section{Tabel 1. Contoh Teks Wawancara Fenomenologi}

\section{Peneliti/Partisipan Pertanyaan/jawaban}

Peneliti

Dalam keseharian, apakah anda sudah melakukan pengelolaan keuangan pribadi atau rumah tangga? Jika sudah, apa yang dilakukan?

Partisipan

Kalau keuangan dulu biasanya yang ngatur suami. Aku cuma dikasih saat butuh aja. Tapi akhir-akhir ini baru mulai benerin cash flow, baru sadar kalo ternyata belum mencoba investasi sama sekali. Jadi, kemarin saya ikut kulwap finansialnya@annisaast. Isi sheet cashflow. Besok baru mau mengutak atik budget mana yang harus dibatasi. Semoga bisa disiplin. 
Berikutnya tahap ke tiga yaitu Developing Emergent Themes. Transkrip dibaca berulang kali untuk menangkap hal menarik yang dikatakan subjek. Pada Tabel 2 di kolom sebelah kiri, teks bercetak tebal digunakan untuk menandai kata-kata menarik atau bermakna yang dikatakan oleh subjek. Sedangkan kolom sebelah kanan digunakan untuk memberikan tema terhadap hal bermakna yang dikatakan subjek.

Tabel 2. Pengkodean Subjek

Pertanyaan/jawaban

Tema

Dalam keseharian, mbak sudah melakukan pengelolaan keuangan pribadi atau rumah tangga? Jika sudah, apa yang dilakukan?

Kalau keuangan dulu biasanya yang ngatur suami. Aku cuma dikasih saat butuh aja. Tapi akhir-akhir ini baru mulai benerin cash flow, baru sadar kalo ternyata belum mencoba investasi sama sekali. Jadi, kemarin saya ikut kulwap finansialnya @annisaast. Isi sheet cashflow. Besok baru mau mengutak atik budget mana yang harus dibatasi. Semoga bisa disiplin.

Pada tahap keempat yaitu Searching for connection a cross emergent themes. Dilakukan pencarian hubungan antar tema-tema yang muncul, hal ini dilakukan setelah menetapkan seperangkat subkategori tema pada text transkrip dan diurutkan secara kronologis. Hubungan antar tema-tema ini dibuat dalam bentuk tabel dan dilihat apakah terdapat tema yang bersesuaian satu sama lain seperti pada Tabel 3 .

Tabel 3. Tema yang Dihasilkan

\begin{tabular}{|c|c|c|}
\hline Hal menarik & Kelompok Tema & Sub Tema \\
\hline Benerin cashflow & Alasan mengatur keuangan & . $\quad$ Mengatur arus kas \\
\hline Mencoba investasi & & . Berinvestasi \\
\hline Semoga bisa disiplin & & · Disiplin \\
\hline Ikut kulwap finansial & Langkah Mengatur keuangan & . Belajar manajemen keuangan \\
\hline Isi sheet cashflow & & . Mencatat arus kas \\
\hline Mengutak atik budget & & . Mengatur arus kas \\
\hline
\end{tabular}

Berikutnya adalah Moving the next cases, Tahapan analisis 1 hingga 4 dilakukan pada setiap satu kasus. Jika satu kasus selesai dan dituliskan hasil analisisnya maka tahap selanjutnya berpindah pada kasus berikutnya.

\subsubsection{User Persona}

User persona adalah karakter fiksi yang dibuat untuk merepresentasikan target pengguna yang akan menggunakan suatu produk. Pada penelitian ini user persona didapatkan dari hasil proses survey dan hasil dari analisis fenomenologis. User persona digunakan untuk mempermudah dalam menggambarkan pengguna beserta permasalahan dan tujuannya sehingga dapat lebih mudah dalam merumuskan strategi memenuhi kebutuhan pengguna. Berikut adalah gambaran user persona dari aplikasi pengelolaan keuangan digambarkan pada Gambar 3. 


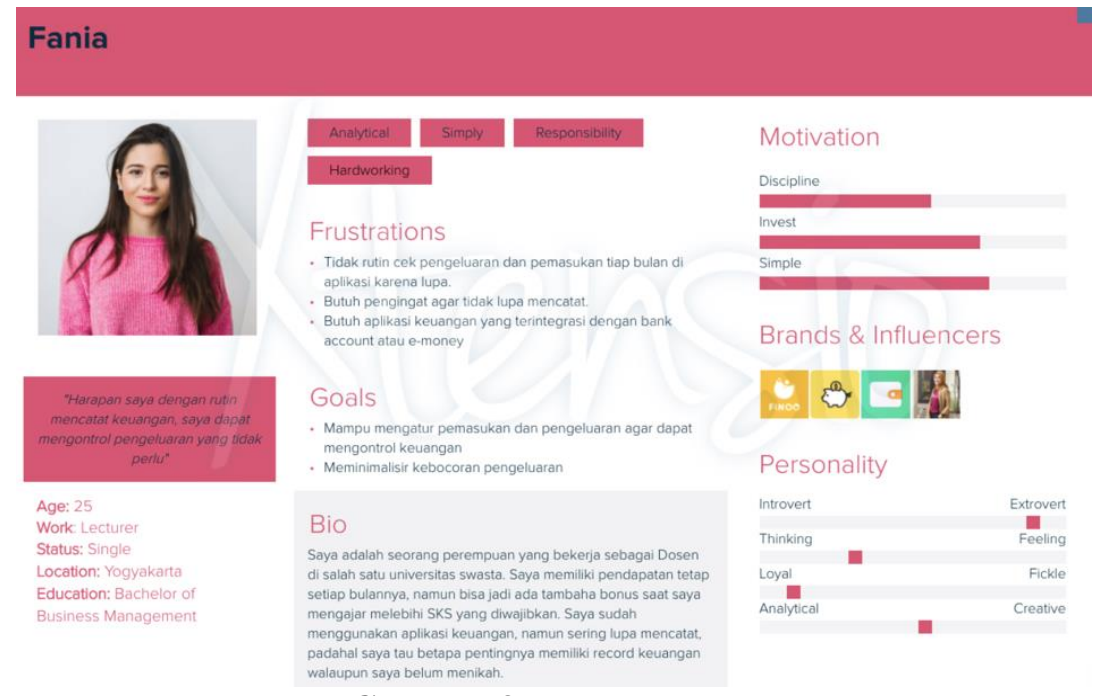

\subsubsection{Tahap Scope}

Gambar 3. User Persona

Pada tahap Scope dilakukan pemetaan perjalanan pengguna atau user journey mapping yang berisi pengalaman seseorang dalam melakukan pengelolaan keuangan pribadinya. Dalam penelitian ini, elemen yang digunakan antara lain (1)Scenario mapping yang berisi tahapan seseorang dalam melakukan pengelolaan keuangan dari awal mendapatkan pemasukan sampai melakukan review pengeluaran. Kemudian yang kedua (2)Customer Goals berisi tujuan akhir dari pengguna pada fase pada scenario mapping, berikutnya (3)Customer Action yaitu langkah yang dilakukan pengguna pada setiap fase atau tahapan pengelolaan keuangan. (4)User Experience, berisi temuan pengalaman pengguna ketika melakukan langkah-langkah pada Customer Action, yang mana pengalamn tersebut dapat berupa pengalaman baik maupun pengalaman yang buruk. Sedangkan (5)Touchpoint merupakan solusi yang dapat diberikan untuk menyelesaikan permasalahan yang ditemukan pada bagian (4)User experience.

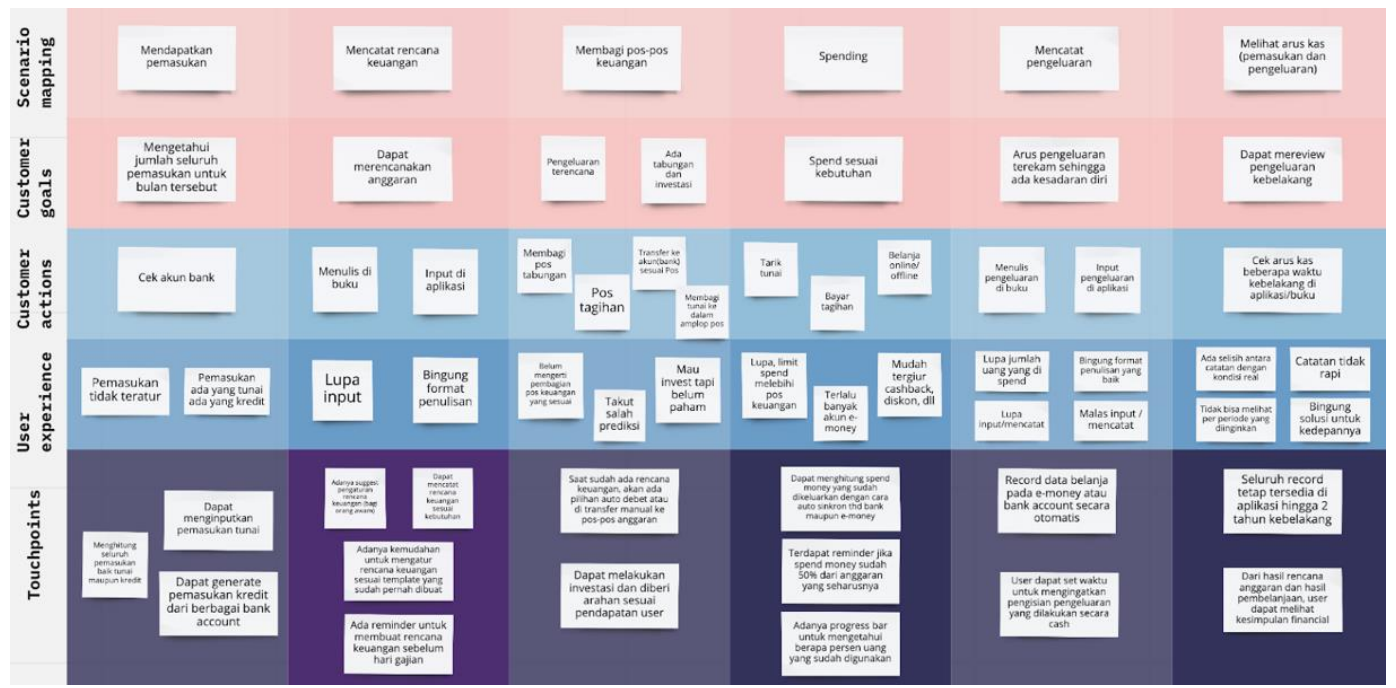

\section{Gambar 4. User Journey Map}

Berdasarkan pemetaan user journey pada Gambar 4, permasalahan yang dialami pengguna pada setiap tahapan ketika melakukan manajemen keuangan pribadinya diidentifikasi pada bagian User Experience. Rekomendasi solusi dari permasalahan tersebut dapat dirumuskan per setiap tindakan atau action yang dilakukan pengguna dan berdasarkan pengalaman mereka. Solusi tersebut peneliti tuliskan pada bagian Touchpoint. Solusi ini yang nantinya menjadi fitur kebutuhan fungsional dan kebutuhan konten pengguna pada rancangan. Fitur kebutuhan fungsional dan kebutuhan konten yang telah dirumuskan dapat dilihat pada Tabel 4 berikut: 
Tabel 4. Kebutuhan Fungsional dan Konten Pengguna

\section{Kebutuhan Fungsional}

a. Koneksi ke akun bank dan e-money

b. Notifikasi pengingat saat : lupa mengisi catatan, pengeluaran melewati batas anggaran

c. Kategorisasi tujuan keuangan

d. Pencatatan arus kas

e. Perhitungan untuk memprediksi risiko

f. Laporan keuangan per periode

g. Penasehat keuangan virtual berdasarkan profil maupun aktivitas $u s e r$

h. Simulasi perhitungan investasi dan dana pendidikan

i. Penyaluran Zakat

\subsubsection{Tahap Structure}

Berikutnya pada tahap Structure ini dilakukan pembuatan User Flow untuk menggambarkan alur saat pengguna menggunakan produk dan bagaimana urutan antarmuka ditampilkan. User flow dirancang dengan mengadaptasi dari Customer Actions dan Touchpoint pada peta perjalanan pengguna atau user journey map. Hasil dari User Flow dapat dilihat pada Gambar 5 berikut. Setelah didapatkan alur pengguna maka dapat dirancang struktur dari tampilan secara keseluruhan seperti pada Gambar 6.

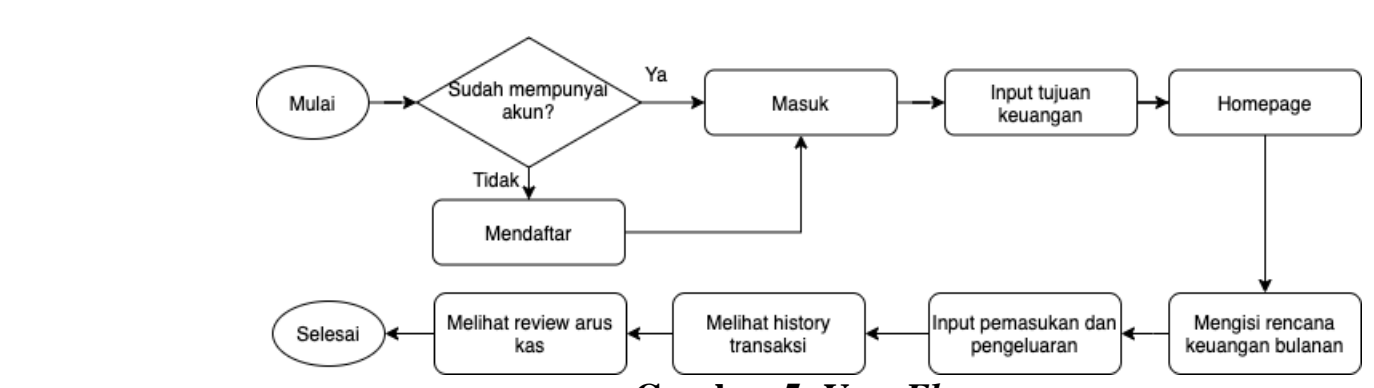

Gambar 5. User Flow
a. Tips pengelolaan keuangan
b. Informasi tentang investasi
c. Rekomendasi pengisian anggaran agar lebih berhemat
d. Artikel berita terkait keuangan seperti update harga emas, obligasi dan saham
e. Template perencanaan anggaran

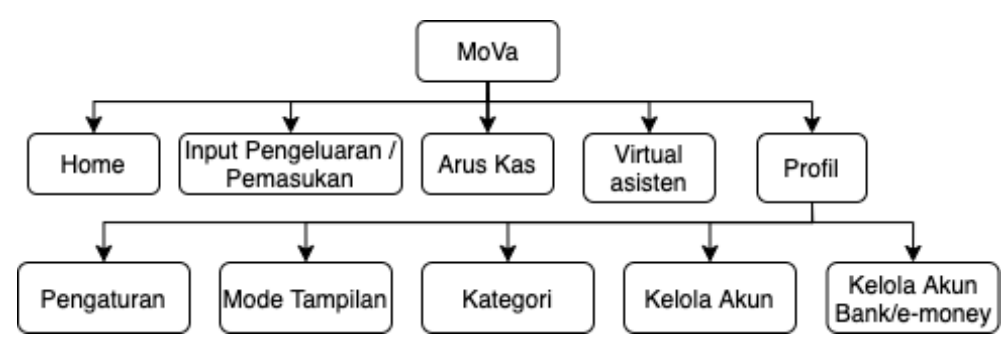

Gambar 6. Desain Struktur Tampilan

\subsubsection{Tahap Skeleton}

Fokus utama pada tahap Skeleton adalah prototipe presisi rendah. Tahap ini menghasilkan komponen desain antarmuka seperti pada Gambar 7. Sketsa dibuat untuk melihat detail apa saja yang harus ada di setiap halaman, bagaimana tata letak navigasi, tombol, judul, gambar dan konten lainnya serta bagaimana alurnya dari satu halaman ke halaman lain berdasarkan referensi dari User Flow pada tahapan Structure. 


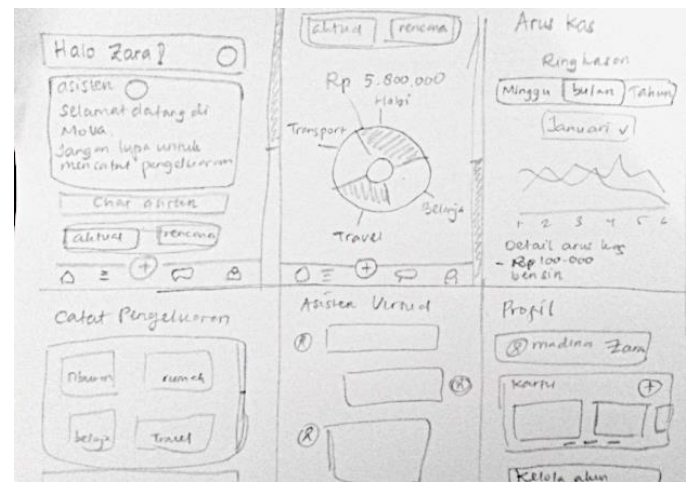

Gambar 7. Sketsa Desain Antarmuka

\subsubsection{Tahap Surface}

Hasil sketsa yang sudah dibuat pada tahap Skeleton, kemudian diperjelas ukuran, warna, bentuk fon, dan lain-lain dalam proses pembuatan mockup. Gambaran kebutuhan fungsional pengguna juga sangat membantu dalam proses pembuatan tampilan visual mockup. Gambar 8 sampai dengan Gambar 13 berikut adalah hasil rancangan mockup.
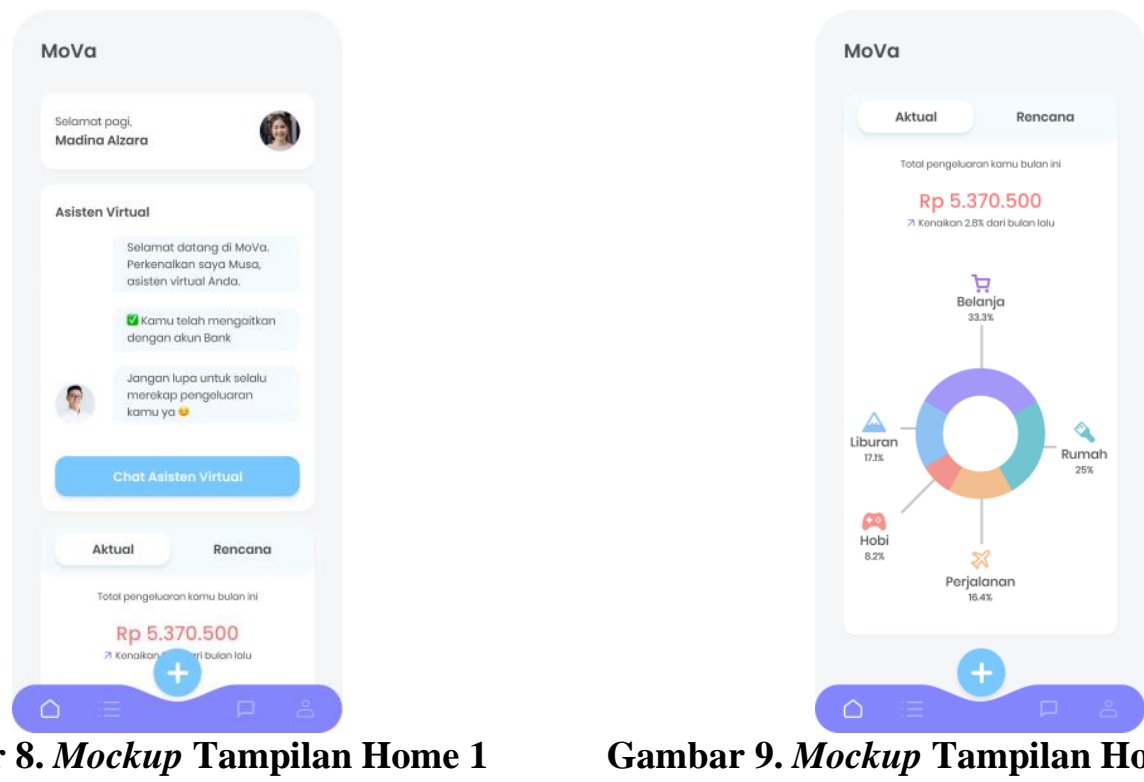

\section{Gambar 8. Mockup Tampilan Home 1}

Gambar 9. Mockup Tampilan Home Scrolling

Gambar 8 menunjukkan tampilan halaman utama dimana pengguna dapat melihat fitur-fitur apa saja yang tersedia dalam aplikasi. Pada tampilan ini pengguna dapat melihat notifikasi terbaru dari asisten virtual berupa percakapan yang dapat berisi konten edukasi maupun informasi terbaru tentang investasi. Gambar 9 masih berada di halaman utama setelah di gulir, menampilkan ringkasan arus kas di bulan ini serta perencanaan anggaran di bulan ini. 


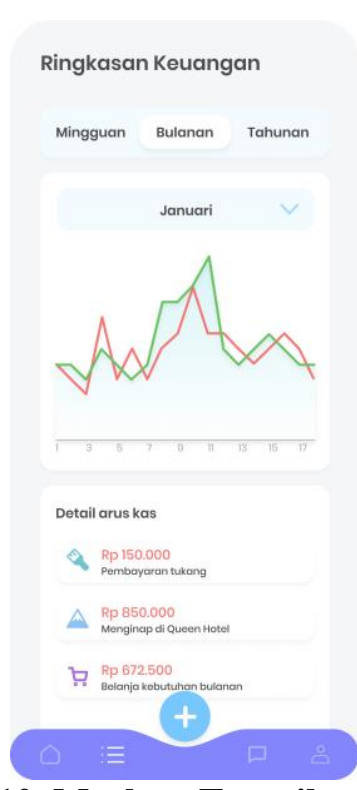

Gambar 10. Mockup Tampilan Arus Kas

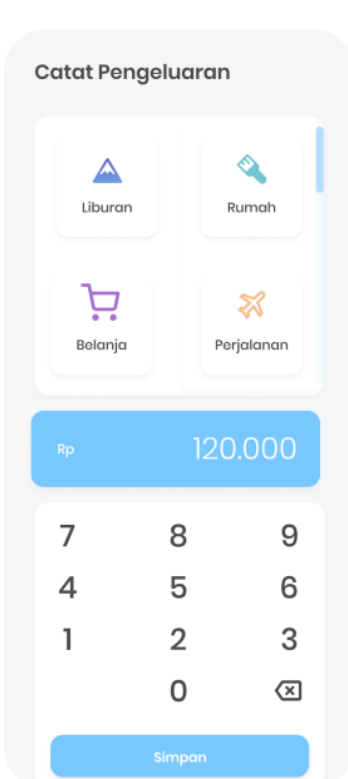

Gambar 11. Mockup Tampilan Catat

Pengeluaran

Gambar 10 merupakan tampilan review arus kas yang dapat dilihat dalam rentang waktu mingguan, bulan dan tahunan. Terdapat pula detail pengeluaran dan pemasukan di bagian bawah grafik. Tombol tambah merupakan menu untuk input pengeluaran maupun pemasukan. Tampilan input pengeluaran ada pada gambar 11.

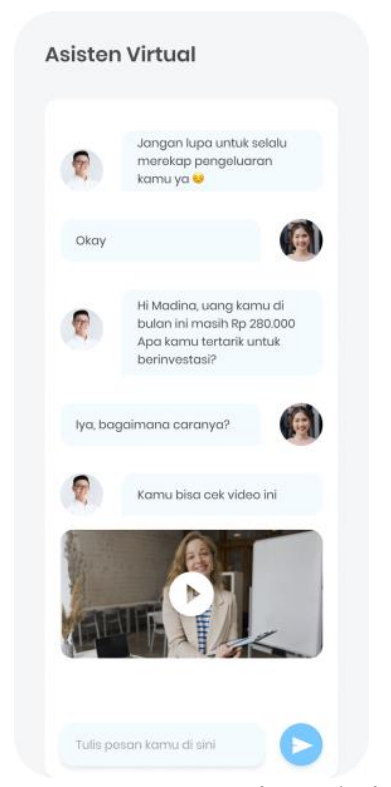

Gambar 12. Mockup Tampilan Asisten Virtual

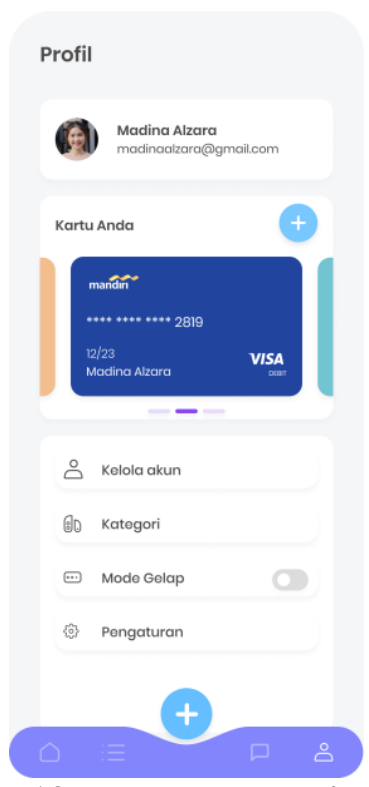

Gambar 13. Mockup Tampilan Profil

Gambar 12 merupakan tampilan komunikasi dengan asisten virtual yang dapat membantu dan mengedukasi tentang mengelola keuangan personal. Gambar 13 adalah tampilan profil yang berisi menu untuk mengelola akun, mengelola kategori pengeluaran dan pemasukan, pengaturan tampilan serta pengaturan aplikasi seperti notifikasi dan kata sandi.

\section{Kesimpulan}

Dalam penelitian ini, antarmuka untuk pengelolaan keuangan personal telah dirancang dengan menggunakan five planes method dan analisis fenomenologis. Five Planes Method dan analisis fenomenologis interpretatif dapat membantu mendefinisikan kebutuhan pengguna secara detail untuk merancang antamuka atau user interface. Fitur fungsional dan kebutuhan konten dalam antarmuka 
aplikasi pengelolaan keuangan personal yang berhasil didapatkan dalam penelitian ini yaitu dapat terkoneksi ke akun bank dan e-money, terdapat notifikasi pengingat saat lupa mengisi catatan dan ketika pengeluaran melewati batas anggaran, adanya kategorisasi tujuan keuangan, pencatatan arus kas, perhitungan untuk memprediksi risiko, laporan keuangan per periode, penasehat keuangan virtual berdasarkan profil maupun aktivitas pengguna, simulasi perhitungan investasi dan dana pendidikan, penyaluran zakat, tips pengelolaan keuangan, informasi tentang investasi, rekomendasi pengisian anggaran agar lebih berhemat, artikel berita terkait keuangan dan investasi, dan template perencanaan anggaran keuangan. Hasil pada penelitian ini dapat menjadi pedoman merancang antarmuka dalam domain teknologi pengelolaan keuangan personal.

\section{Referensi}

[1] W. Kenton, "Personal Finance." [Online]. Available: https://www.investopedia.com/terms/p/personalfinance.asp. [Accessed: 07-Jun-2020].

[2] Ardiansyah, "Analisis Pengambilan Keputusan Berbasis Personal Finance Information Systems," Snastik 2012, vol. 55164, no. 5. 2012.

[3] OJK, "Strategi Nasional Literasi Keuangan Indonesia (Revisit 2017)," Otoritas Jasa Keuang., pp. 1-99, 2017.

[4] H. Lasi, P. Fettke, H.-G. Kemper, T. Feld, and M. Hoffmann, "Industry 4.0," Bus. Inf. Syst. Eng., vol. 6, no. 4, pp. 239-242, 2014.

[5] B. Indonesia, "Statistik Sistem Pembayaran (SSP)." [Online]. Available: https://www.bi.go.id/id/statistik/ekonomi-keuangan/ssp/uang-elektronik-jumlah.aspx. [Accessed: 09-Apr-2020].

[6] W. Jati, "less cash society: menakar mode konsumerisme baru kelas menengah indonesia," J. Sosioteknologi, vol. 14, pp. 102-112, 2015.

[7] M. Mumpuni and S. Soekarno, "Design and Implementation Money Management Web Based Application for Personal and Family Proposed for CV. X," Procedia - Soc. Behav. Sci., vol. 115, pp. 444-459, 2014.

[8] A. Syahrina and T. Kusumasari, "Designing User Experience and User Interface of a B2B Textile e-Commerce using Five Planes Framework," Int. J. Innov. Enterp. Syst., vol. 4, pp. 4455, 2020.

[9] J. Smith, P. Flowers, and M. Larkin, Interpretative Phenomenological Analysis: Theory, Method and Research, vol. 6. 2009.

[10] J. Linder and M. Arvola, "IPA in UX Research: Interpretative Phenomenological Analysis in a User Experience Design Practice," 2017, pp. 17-24.

[11] J. Garrett, The Elements of User Experience: User-Centered Design for the Web and Beyond. 2010.

[12] T. Strohmann, L. Höper, and S. Robra-Bissantz, "Design Guidelines for Creating a Convincing User Experience with Virtual In-vehicle Assistants," Proc. 52nd Hawaii Int. Conf. Syst. Sci., vol. 6, pp. 4813-4822, 2019.

[13] L. Dewi et al., "Studi Komparasi Alat Bantu Pengelola Keuangan Pribadi Berbasis Mobile Comparative Study Mobile Based," vol. 2, no. 1, 2019.

[14] B. R. Cowan et al., "What Can I Help You with?': Infrequent Users' Experiences of Intelligent Personal Assistants," in Proceedings of the 19th International Conference on Human-Computer Interaction with Mobile Devices and Services, 2017.

[15] F. Wijaya, "Persepsi Orang Tua Terhadap Perilaku Bermain Anak Berdasarkan Gender:(Studi Fenomenologi pada Orang Tua yang Memiliki Anak Usia di bawah Enam Tahun di Kecamatan Cicalengka)," 2015.

[16] B. Atasoy and J. Martens, "STORYPLY: Designing for user experiences using storycraft," 2016, pp. 181-210.

[17] D. Norman and J. Nielsen, "When and How to Create Customer Journey Maps." [Online]. Available: https://www.nngroup.com/articles/customer-journey-mapping/. [Accessed: 11-Sep2019].

[18] A. G. Persada, "Desain Interaksi Menggunakan Metode The Five Planes Pada Studi Kasus Website Penjualan," 2020. 
[19] A. Priana, H. Tolle, I. Aknuranda, and E. Arisetijono, "Design of Mobile Finger Communications Board for Stroke Patient Using The Five Planes of User Experience," J. Inf. Technol. Comput. Sci., vol. 2, 2018.

[20] H. Ali, L. Purwandi, H. Nugroho, A. W. Ekoputri, and T. Halim, "The Urban Middle-Class Indonesia: Financial and Online Behavior," Alvara Res. Cent., 2017. 